\title{
IMPLEMENTASI MODEL PEMBELAJARAN SEARCH, SOLVE, CREATE AND SHARE (SSCS) UNTUK MENINGKATKAN KEMAMPUAN BERPIKIR KREATIF MATEMATIS
}

\section{(IMPLEMENTATION SEARCH, SOLVE, CREATE AND SHARE (SSCS) MODEL TO IMPROVE MATEHEMATICAL CREATIVE THINKING ABILITY)}

\author{
Eva Fitria Ningsih \\ STKIP Pelita Pratama, evafitria91@gmail.com
}

\begin{abstract}
Abstrak
Tujuan utama penelitian ini untuk melakukan studi yang berfokus pada penggunaan model pembelajaran SSCS yang diduga dapat meningkatkan kemampuan berpikir kreatif matematis, ditinjau dari keseluruhan siswa dan kategori Kemampuan Awal Matematika (KAM) siswa (unggul dan asor). Metode penelitian yang digunakan dalam penelitian ini merupakan metode kuasi eksperimen. Penelitian ini menggunakan tes KAM dan tes kemampuan berpikir kreatif matematis. Pengolahan data dalam penelitian ini menggunakan uji-t dan ANOVA dua jalur. Berdasarkan hasil analisis data didapatkan kesimpulan bahwa ditinjau dari keseluruhan, peningkatan kemampuan berpikir kreatif matematis siswa yang memperoleh model pembelajaran SSCS lebih baik daripada kemampuan berpikir kreatif matematis siswa yang memperoleh pembelajaran ekspositori. Apabila ditinjau dari kategori KAM, peningkatan kemampuan berpikir kreatif matematis siswa unggul dan asor yang memperoleh model pembelajaran SSCS lebih baik daripada kemampuan berpikir kreatif matematis siswa unggul dan asor yang memperoleh pembelajaran ekspositori.
\end{abstract}

Kata kunci: Model SSCS, Kemampuan Berpikir Kreatif Matematis

\begin{abstract}
The main purpose of this resaerch was to conduct a study focusing on the use SSCS model is assumed capable to improve students mathematical creative thinking ability based on student of all and Prior Mathematical Ability (PMA) students (high and low). The method of this research is a quasi experimet method. This research used two kinds of instruments: PMA test and mathematical creative thinking ability test. This research used Independent Sample t-Test and Two-Way ANOVA. Conclusion of this research are based on students of all, the enhancement mathematical creative thinking ability of students who were given SSCS model are better than students who were given expository learning. When based on PMA category, increase mathematical creative thinking ability of students high and low who were given SSCS model are better than students who were given expository learning.
\end{abstract}

Keywords: SSCS Model, Mathematical creative thinking ability 


\section{PENDAHULUAN}

Kemampuan berpikir diperlukan setiap individu untuk mampu bertahan dalam persaingan global. Menurut Sumarmo (2010), kemajuan Ilmu Pengetahuan dan Teknologi (IPTEK), tantangan, tuntutan, dan persaingan global yang semakin ketat membutuhkan manusia yang memiliki kemampuan berpikir logis, kritis, dan kreatif, serta disposisi matematika. Fokus kemampuan berpikir kreatif juga ditemukan dalam pembelajaran matematika. Ini dapat dilihat pada salah satu isi dari Standar Kompetensi Lulusan (SKL) mata pelajaran matematika (Depdiknas, 2006), mata pelajaran matematika perlu diberikan kepada semua peserta didik mulai dari sekolah dasar untuk membekali peserta didik dengan kemampuan berpikir logis, analitis, sistematis, kritis, dan kreatif, serta kemampuan bekerjasama. Kompetensi tersebut diperlukan agar peserta didik dapat memiliki kemampuan memperoleh, mengelola, dan memanfaatkan informasi untuk bertahan hidup pada keadaan yang selalu berubah, tidak pasti, dan kompetitif.

Sejalan dengan hal tersebut, menurut Sabandar (2008), pentingnya kehadirian proses berpikir dalam proses pembelajaran matematika salah satunya adalah terdapat tuntutan dalam kurikulum yang berlaku untuk dicapainya kemampuan berpikir kritis dan berpikir kreatif agar nantinya individu dapat menjawab tuntutan dalam rangka menyesuaikan diri dengan perkembangan peradaban, serta tuntutan dalam perbaharuan tentang standardisasi instrumeninstrumen tes yang mengukur kapasitas siswa secara aktif dalam mengaplikasikan pengetahuan.

Pada pembelajaran matematika di sekolah, hendaknya siswa dilatih untuk memiliki ketrampilan berpikir kreatif. Pentingnya kretivitas dalam matematika dikemukakan oleh Kiesswetter (Pehnoken, 1997) menyatakan bahwa, berpikir fleksibel yang merupakan salah satu komponen dari kreativitas adalah salah satu kemampuan paling penting yang harus dimiliki siswa dalam menyelesaikan masalah matematika. Selain itu menurut Sumarmo (2010), pentingnya keterampilan berpikir kreatif dilatihkan kepada siswa, didukung oleh visi pendidikan matematika yang memiliki dua arah pengembangan, yaitu memenuhi kebutuhan masa kini dan masa yang akan datang. Visi pertama untuk kebutuhan masa kini, pembelajaran matematika mengarah pada konsep-konsep yang diperlukan untuk menyelesaikan masalah matematika dan ilmu pengetahuan lainnya.Visi kedua untuk kebutuhan masa yang akan datang mempunyai arti luas, yaitu pembelajaran matematika memberikan kemampuan nalar yang logis, sistematis, cermat, berpikir objektif dan terbuka, yang diperlukan dalam kehidupan sehari-hari serta untuk menghadapi masa depan yang selalu berubah.

Menurut Munandar (1999), berpikir kreatif (juga disebut berpikir divergen) ialah memberikan macam-macam kemungkinan jawaban berdasarkan informasi yang diberikan dengan penekanan pada keragaman jumlah dan kesesuaian. Sedangkan menurut Facione (McGregor, 2007), berpikir kreatif merupakan salah satu jenis berpikir yang mengarahkan diperolehnya wawasan baru, pendekatan baru, perspektif baru, atau cara baru dalam memahami sesuatu. Berpikir kreatif dapat terjadi ketika dipicu oleh tugas-tugas atau masalah yang menantang.

Menyadari pentingnya suatu sistem pembelajaran untuk mengembangkan kemampuan berpikir kreatif matematis siswa, maka mutlak 
diperlukan adanya pembelajaran matematika yang lebih banyak melibatkan aktivitas berpikir siswa. Menurut Ruseffendi (2006) kreativitas siswa dapat dikembangkan apabila dilatih melalui eksplorasi, inkuiri, penemuan, dan pemecahan masalah. Hal ini sejalan dengan sebuah model pemecahan masalah khusus untuk pengajaran sains yang diusulkan oleh Pizzini, Shepardson, dan Abell (1988) atas pemikiran bahwa untuk menjadikan suatu masalah menjadi bermakna bagi siswa, maka perlu diidentifikasi dan ditentukan sendiri oleh siswa, dan siswa belajar memecahkan masalah dan konsep-konsep ilmu pengetahuan melalui pengalaman nyata. Model ini diberi nama model Search, Solve, Create and Share (SSCS) yang terdiri dari empat tahap/fase: Search, Solve, Create and Share.

Berdasarkan uraian tersebut, maka peneliti ingin melakukan penelitian terkait model pemecahan masalah khusus Search, Solve, Create and Share (SSCS) untuk meningkatkan kemampuan berpikir kreatif matematis siswa. Oleh karena itu, peneliti tertarik untuk melakukan penelitian dengan judul "Implementasi Model Pembelajaran Search, Solve, Create and Share (SSCS) untuk Meningkatkan Kemampuan Berpikir Kreatif Matematis".

\section{KAJIAN TEORI}

\section{Model Pembelajaran Search, Solve, Create and Share (SSCS)}

Model SSCS mengacu pada empat langkah penyelesaian masalah yang urutannya dimulai dengan penyelidikan masalah (search), merencanakan penyelesaian (solve), mengkonstruksi pemecahan masalah (create), dan mendiskusikan penyelesaian masalah (share).

Berikut ini akan dibahas secara rinci aktivitas siswa pada setiap fase pada model SSCS.

Tabel 1. Aktivitas Siswa pada Setiap Fase

\begin{tabular}{|c|c|c|}
\hline $\begin{array}{c}\text { Model } \\
\text { Pemecahan } \\
\text { Masalah SSCS }\end{array}$ & $\begin{array}{c}\text { Pertanyaan / Tugas / } \\
\text { Pendekatan }\end{array}$ & Proses / Keterampilan \\
\hline & $\begin{array}{l}\text { Kenali masalah } \\
\text { Apa? Siapa? Kapan? Di } \\
\text { Mana? Bagaimana? }\end{array}$ & $\begin{array}{c}\text { Brainstorming, Mengamati, } \\
\text { Menganalisis, } \\
\text { Mengklasifikasikan, } \\
\text { Mengukur, dan } \\
\text { menggambarkan. }\end{array}$ \\
\hline $\begin{array}{c}\text { Search } \\
\text { (Menyelidiki) }\end{array}$ & $\begin{array}{c}\text { Carilah Informasi lain apakah } \\
\text { terdapat sesuatu yang lain } \\
\text { yang perlu diketahui? } \\
\text { Dimana hal itu dapat } \\
\text { ditemukan? }\end{array}$ & $\begin{array}{l}\text { Mempertanyakan, Mencari } \\
\text { kepustakaan dan Bertanya. } \\
\text { Brainstorming, membuat } \\
\text { hipotesis, Memprediksi, } \\
\text { Evaluasi, Pengujian. }\end{array}$ \\
\hline & $\begin{array}{l}\text { Buat daftar masalah / ide dari } \\
\text { situasi. } \\
\text { Menyatakan masalah. }\end{array}$ & $\begin{array}{l}\text { Brainstorming, Memfokuskan, } \\
\text { Bertanya, Membandingkan, } \\
\text { Memeriksa, dan Menganalisa. }\end{array}$ \\
\hline $\begin{array}{c}\text { Solve } \\
\text { (Merencanakan }\end{array}$ & $\begin{array}{l}\text { Menghasilkan daftar dari } \\
\text { pendekatan atau ide untuk }\end{array}$ & $\begin{array}{l}\text { Pengambilan keputusan, } \\
\text { Mendefinisikan, Membuat, }\end{array}$ \\
\hline
\end{tabular}




\begin{tabular}{|c|c|c|}
\hline Penyelesaian) & $\begin{array}{c}\text { digunakan. } \\
\text { Rencananya - apa itu? } \\
\text { Melaksanakan rencana } \\
\text { tersebut }\end{array}$ & $\begin{array}{c}\text { Merancang, } \\
\text { Menerapkan, Mensintesis, } \\
\text { Pengujian dan Verifikasi }\end{array}$ \\
\hline $\begin{array}{c}\text { Create } \\
\text { (Mengkonstruksi } \\
\text { Penyelesaian) }\end{array}$ & $\begin{array}{l}\text { Menciptakan produk atau ide. } \\
\text { Evaluasi diri dari proses dan / } \\
\text { atau solusi. }\end{array}$ & $\begin{array}{l}\text { Menerima, Menolak, } \\
\text { Memodifikasi, } \\
\text { Menyempurnakan, } \\
\text { Melengkapi, } \\
\text { Mengkomunikasikan } \\
\text { penyelesaian masalah, } \\
\text { Menampilkan, } \\
\text { Mempromosikan dan } \\
\text { Mengevaluasi. }\end{array}$ \\
\hline $\begin{array}{c}\text { Share } \\
\text { (Mendiskusikan) }\end{array}$ & $\begin{array}{l}\text { Komunikasi dan interaksi. } \\
\text { Artikulasi berpikir. Umpan } \\
\text { balik. Evaluasi solusi. } \\
\text { Menghasilkan pertanyaan } \\
\text { pencarian potensial. }\end{array}$ & $\begin{array}{c}\text { Mempromosikan, } \\
\text { Menampilkan, Pelaporan, } \\
\text { verbalisasi, mempertanyakan, } \\
\text { Meninjau, dan memverifikasi. }\end{array}$ \\
\hline
\end{tabular}

Sumber: Pizzini, Shepardson, dan Abel (Lartson, 2013)

\section{Kemampuan Berpikir Kreatif Matematis}

Kreativitas telah menarik perhatian besar dan telah dipelajari dalam berbagai cara oleh para peneliti, terutama sejak Guilford (1950) membahas pentingnya kreativitas pada American Psychological Association. Produk divergen menjadi salah satu bidang utama di bidang kreativitas, bersama dengan faktor-faktor seperti kelancaran, kebaruan, fleksibilitas, kemampuan sintesis, kemampuan analisis, evaluasi, originalitas, elaborasi, pemecahan masalah. Produksi divergen adalah istilah yang dibuat Guilford untuk berpikir divergen (Runco dalam Park, 2004).

Guilford (Park, 2004) medefinisikan produk divergen sebagai kemampuan untuk menghasilkan beberapa solusi, dimana keragaman dan banyaknya hasil ditekankan. Terdapat empat komponen kemampuan produksi divergen yang penting atau berkontribusi untuk kreativitas yaitu fluency (kelancaran), flexibility (keluwesan), originality (kebaruan), dan elaboration (elaborasi/keterincian). Setiap komponen didefinisikan oleh Guilford (1973) sebagai berikut: Fluency (kelancaran) adalah kemampuan untuk memikirkan banyak ide; banyak kemungkinan solusi untuk masalah.; flexibility (keluwesan) adalah kemampuan untuk melampaui tradisi, kebiasaan, untuk mengubah ide dan untuk menggunakan cara baru, berbeda, dan tidak biasa.; originality (kebaruan) yaitu mampu memunculkan ide-ide yang tidak biasa; dan elaboration (elaborasi) yaitu kemampuan untuk menyusun rincian dari ide atau solusi.

Menurut Pehnoken (1997), kreativitas tidak hanya ditemukan dalam bidang tertentu, seperti seni dan sains, melainkan juga merupakan bagian dari kehidupan. Contohnya, manusia memanfaatkan pemikiran kreatif ketika ia memecahkan 
masalah-masalah praktis. Oleh karena itu, kreativitas harus menjadi bagian intrinsik dari "matematika".

Menurut Sabandar (2008) berpikir dalam pembelajaran matematika dapat muncul diawali oleh adanya kepekaan terhadap suatu situasi yang mengandung masalah/pertanyaan yang ingin dicari jawaban atau solusinya. Beberapa hal yang terkait dengan berpikir kreatif antara lain;

a. Kepekaan

Kepekaan atau sensitivity dapat dimunculkan lewat pemahaman terhadap situasi dan pemahaman terhadap apa yang ingin dicapai atau tujuan dari permasalahan tersebut

b. Originalitas

Originalitas dapat dimunculkan jika diinginkan bahwa ide atau strategi yang akan digunakan oleh individu pembelajar untuk mengkaji masalah itu adalah suatu strategi yang relatif baru bagi individu yang bersangkutan, suatu strategi yang berbeda dari strategi yang biasa ia gunakan ataupun orang lain gunakan

c. Kelancaran

Momentum pada proses berpikir perlu dipertahankan. Tidak sering ketika individu sedang berpikir untuk menyelesaikan suatu masalah ia mengalami kebuntuan. Ketika kebuntuan ini muncul dan tidak diupayakan adanya tindakan / langkah yang tepat, maka proses berpikir dapat terhenti. Untuk ini, individu dapat segera bertindak untuk mencoba menggunakan strategi-strategi lain, dan tidak hanya bertahan pada strategi yang tidak membawanya pada solusi.

d. Keluwesan

Fleksibilitas adalah suatu pola pikir yang tidak hanya terpaku pada satu cara, atau pola pikir yang tidak memandang bahwa hanya ada satu jawab yang benar atau hanya ada satu cara yang benar sedangkan cara lain adalah tidak/kurang tepat. Pola fleksibilitas sesungguhnya perlu dimunculkan dalam proses berpikir matematika sehingga individu akan terlatih untuk melihat dan menyelesaikan masalah dari perspektif yang berbeda yang selanjutnya dapat menumbuhkan self eficcacy (rasa yakin akan kemampuan diri sendiri).

Fleksibilitas ini dapat dipertahankan dengan cara menuliskan suatu rubrik tentang apa yang sudah dikerjakan namun belum berhasil, ataupun gagasan apa yang dapat digunakan untuk memikirkan penyelesaian dari masalah itu. Hanya dengan membuat rubrik, maka individu dapat melacak apa yang telah dikerjakan dan dipikirkan, sehingga ketika ia siap lagi ia dapat melanjutkan proses berpikirnya. Keberhasilan dalam menemukan solusi perlu ditindak lanjuti dengan upaya untuk menyelesaikan masalah yang sama dengan cara lain atau beragam cara (flexibility).

e. Elaborasi/penyempurnaan/detail/rinci

Elaborasi merupakan bagian dari proses berpikir dimana suatu ide/solusi yang original akan muncul dengan sangat cepat dan individu perlu merespons secara cepat sebelum ide itu menjadi lapuk. Karena itu seringkali solusi atau ide itu dimunculkan pada kertas (buram). Disini hanya terlihat langkah-langkah penting secara garis besar. Namun untuk keperluan mempelajari lagi solusi itu untuk tujuan-tujuan lanjutan, maka diperlukan agar ada proses elaborasi. Dalam proses ini, hasil pemikiran individu yang original dan secara garis besar itu ditata dengan lebih rinci dan distruktur secara sistematis.

\section{METODE PENELITIAN}

Metode penelitian yang digunakan adalah desain eksperimen semu (Quasi- 
Experiment) yaitu dilakukan tanpa proses teknik sampel peluang (Fraenkel \& Wallen dalam Indrawan dan Yaniawati, 2014), kemudian memilih dua kelas yang setara di tinjau dari kemampuan akademiknya. Kelas yang pertama meperoleh model SSCS (kelas eksperimen) dan kelas kedua memperoleh pembelajaran ekspositori (kelas kontrol).

Instrumen yang digunakan adalah tes kemampuan berpikir kreatif matematis. Tes yang digunakan dalam penelitian ini adalah tes KAM dan tes kemampuan berpikir kreatif yang telah diuji validitas dan reliabilitasnya. KAM dilakukan untuk mengetahui kemampuan awal matematika siswa kelas kontrol dan kelas eksperimen. Tes kemampuan berpikir kreatif dilakukan untuk mengetahui perubahan secara signifikan kemampuan berpikir kreatif setelah siswa kelompok eksperimen mendapat pembelajaran model pembelajaran SSCS dan siswa pada kelompok kontrol yang mendapat pembelajaran ekpositori.

Penelitian ini mengkaji penggunaan model pembelajaran SSCS terhadap peningkatan kemampuan berpikir kreatif matematis. Pengkajian lebih komprehensif dilakukan dengan meninjau atau melibatkan faktor Kemampuan Awal Matematis (KAM) sebagai variabel kontrol.

\section{HASIL DAN PEMBAHASAN}

Data yang diperoleh pada penelitian ini adalah data kuantitatif. Hasil tes kemampuan berpikir kreatif matematis terdiri dari skor pretes dan postes. Untuk mengetahui peningkatan kemampuan berpikir kreatif matematis siswa dilihat dari skor gain. Hasil yang diperoleh adalah peningkatan kemampuan berpikir kreatif matematis siswa kelas eksperimen juga lebih baik daripada siswa kelas kontrol. Hal tersebut ditunjukkan dengan perolehan skor gain pada kelas eksperimen yang lebih tinggi daripada kelas kontrol yang dapat dilihat dengan jelas pada diagram dibawah ini:

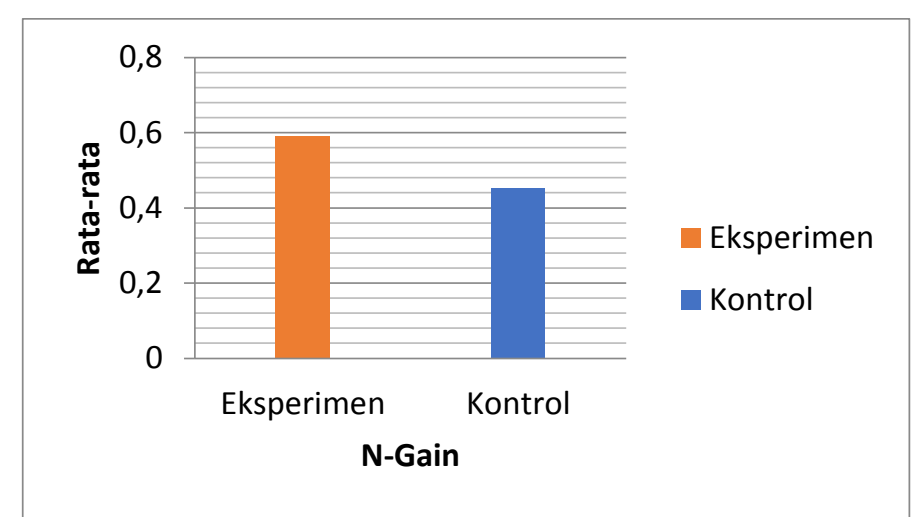

Diagram 1. Rata-rata Peningkatan Kemampuan Berpikir Kreatif Matematis

Perbedaan peningkatan kemampuan berpikir kreatif matematis siswa ditinjau dari ranah KAM ditunjukkan dengan perolehan skor gain pada kelas eksperimen dan kelas kontrol yang dapat dilihat dengan jelas pada diagram dibawah ini: 


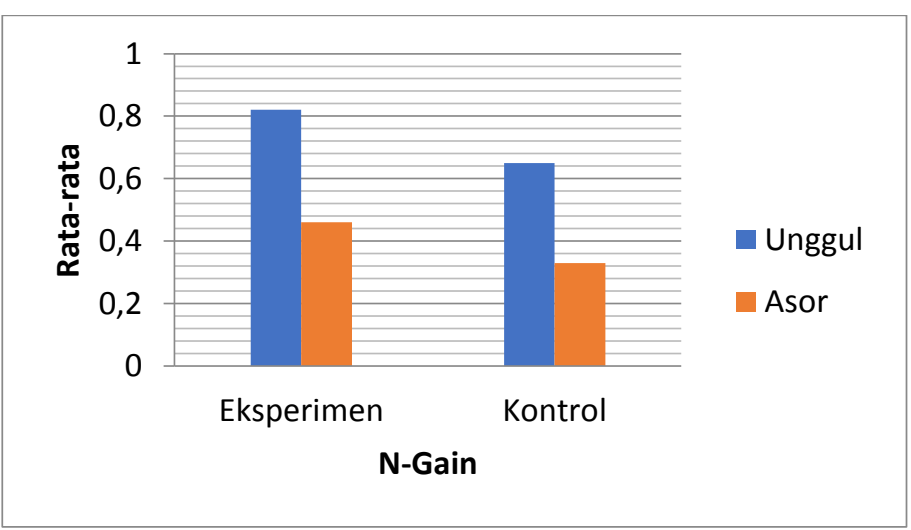

Diagram 2. Rata-rata Peningkatan Kemampuan Berpikir Kreatif Matematis Ditinjau dari Ranah KAM

Pada Diagram 2 tampak bahwa rata-rata gain kemampuan berpikir kreatif matematis siswa yang memperoleh model pembelajaran SSCS lebih tinggi daripada siswa yang memperoleh pembelajaran ekspositori di setiap kelompok KAM. Jika pembelajaran model pembelajaran SSCS diterapkan pada semua kelompok KAM, maka dapat meningkatkan kemampuan berpikir kreatif matematis. Selanjutnya rata-rata gain kemampuan berpikir kreatif matematis tertinggi diperoleh siswa kelas eksperimen kelompok unggul dan rata-rata gain kemampuan berpikir kreatif matematis terkecil diperoleh siswa kelas kontrol kelompok asor.

Untuk mengetahui ada atau tidaknya perbedaan rata-rata empat kelompok data siswa (unggul dan asor), dihitung dengan Uji Kruskal Wallis dengan menggunakan SPSS 20.0 pada Tabel 2.

Tabel 2

Hasil Uji Kruskal Wallis Skor Gain Ternormalisasi berdasarkan Kelompok Unggul-Asor dan Model Pembelajaran

\begin{tabular}{|l|r|}
\hline \multicolumn{2}{|c|}{ Test Statistics $^{\text {a,b }}$} \\
\hline Chi-Square & \multicolumn{1}{|c|}{ N-Gain } \\
Df & 32,237 \\
Asymp. Sig. & 2 \\
\hline
\end{tabular}

a. Kruskal Wallis Test

b. Grouping Variable: KAM

Berdasarkan Tabel 2, nilai Asymp. Sig. 0,000 < 0,05. Hasil uji statistik menerima $\mathrm{H}_{1}$. Artinya terdapat perbedaan yang signifikan rata-rata nilai gain ternormalisasi dari kelompok eksperimen unggul, eksperimen asor, kontrol unggul, dan kontrol asor.

Untuk melihat interaksi antara kemampuan awal matematika (unggul-asor) dan model pembelajaran, dalam hal ini kita melakukan pengujian terhadap hipotesis dengan anova 2 jalur menggunakan SPSS 20.0, hasil perhitunganya sebagai berikut: 
Tabel 3

Hasil Uji Anova Dua Jalur Skor Gain Ternormalisasi berdasarkan Faktor Kemampuan Awal Matematika dan Model Pembelajaran

Tests of Between-Subjects Effects

Dependent Variable: N-Gain

\begin{tabular}{|l|r|r|r|r|r|}
\hline Source & $\begin{array}{c}\text { Type III Sum } \\
\text { of Squares }\end{array}$ & Df & \multicolumn{1}{c|}{$\begin{array}{c}\text { Mean } \\
\text { Square }\end{array}$} & \multicolumn{1}{|c|}{ F } & Sig. \\
\hline Corrected Model & $2,107^{a}$ & 3 &, 702 & 48,727 &, 000 \\
Intercept & 19,601 & 1 & 19,601 & 1360,023 &, 000 \\
Kelas &, 284 & 1 &, 284 & 19,678 &, 000 \\
KAM & 1,791 & 1 & 1,791 & 124,298 &, 000 \\
Kelas * KAM &, 009 & 1 &, 009 &, 595 &, 443 \\
Error &, 894 & 62 &, 014 & & \\
Total & 20,879 & 66 & & & \\
Corrected Total & 3,000 & 65 & & & \\
\hline
\end{tabular}

a. $\mathrm{R}$ Squared $=, 702$ (Adjusted R Squared $=, 688$ )

Berdasarkan tabel 3, kelas memiliki nilai sig 0,000 $<0,05$ maka $\mathrm{H}_{0}$ ditolak. Hal ini berarti terdapat perbedaan yang signifikan mengenai kemampuan berpikir kreatif matematis siswa antara kelas eksperimen dan kontrol.

Kemampuan Awal Matematika (KAM) memiliki nilai sig $0,000<0,05$ maka $\mathrm{H}_{0}$ ditolak. Hal ini berarti terdapat perbedaan yang signifikan mengenai kemampuan berpikir kreatif matematis siswa antara kelompok unggul dan asor.

Kelas*KAM memiliki nilai sig 0,443; karena nilai sig > 0,05, maka $\mathrm{H}_{0}$ diterima. Ini berarti tidak terdapat interaksi antara model pembelajaran dan KAM, atau dapat dikatakan tidak terdapat pengaruh KAM terhadap kedua kelas model pembelajaran dalam hal kemampuan berpikir kreatif matematis.

Berdasarkan analisis terhadap hasil setelah penelitian pada kelompok siswa yang memperoleh model pembelajaran SSCS dan ekspositori dapat disimpulkan bahwa, terdapat perbedaan kemampuan berpikir kreatif matematis siswa unggul dan asor yang memperoleh model pembelajaran SSCS dengan kemampuan berpikir kreatif matematis siswa unggul dan asor yang memperoleh pembelajaran ekspositori. Hal ini menunjukan bahwa kemampuan berpikir kreatif matematis siswa yang memperoleh model pembelajaran SSCS lebih baik daripada kemampuan berpikir kreatif matematis siswa yang memperoleh pembelajaran ekspositori.

Siswa yang memperoleh model pembelajaran SSCS mengalami peningkatan dengan kategori peningkatan sedang, begitu pula siswa yang memperoleh model ekspositori juga mengalami peningkatan dengan kategori peningkatan sedang. Meskipun kedua kelompok mempunyai kategori peningkatan yang sama, tetapi siswa yang memperoleh model pembelajaran SSCS mengalami peningkatan yang lebih tinggi dibandingkan dengan siswa yang memperoleh pembelajaran ekspositori. Jika dilihat berdasarkan KAM, siswa unggul yang memperoleh model pembelajaran SSCS mengalami peningkatan dengan kategori tinggi sedangkan siswa unggul yang memperoleh pembelajaran ekspositori mengalami peningkatan dengan kategori sedang. Siswa asor yang memperoleh model pembelajaran SSCS dan siswa asor yang memperoleh model ekspositori mengalami peningkatan sedang, akan tetapi rata-rata peningkatan siswa asor yang memperoleh model pembelajaran SSCS lebih besar daripada rata-rata peningkatan 
siswa asor yang memperoleh model ekspositori. Hal tersebut dikarenakan dengan model pembelajaran SSCS, siswa banyak diberikan soal-soal non rutin yang mana soal-soal tersebut dapat membuat siswa tertantang dan memacu siswa untuk melakukan aktivitas dan proses berpikir, sehingga dapat membiasakan dan melatih kemampuan berpikir siswa menjadi keterampilan berpikir. Hal tersebut sesuai dengan pendapat Sabandar (2008), proses berpikir dapat dipicu dan berkembang lewat adanya masalah matematika yang menantang dan tidak rutin sehingga peserta didik memiliki kebiasaan berpikir yang memadai dan memiliki ketrampilan berpikir yang memampukan mereka untuk menjadi kritis, kreatif dan reflektif.

\section{SIMPULAN DAN SARAN}

Berdasarkan hasil analisis data disimpulkan bahwa, peningkatan kemampuan berpikir kreatif matematis siswa ditinjau dari keseluruhan antara siswa yang memperoleh model pembelajaran SSCS lebih baik daripada kemampuan berpikir kreatif matematis siswa yang memperoleh pembelajaran ekspositori. Apabila ditinjau dari kategori KAM, peningkatan kemampuan berpikir kreatif matematis siswa unggul dan asor yang memperoleh model pembelajaran SSCS lebih baik daripada kemampuan berpikir kreatif matematis siswa unggul dan asor yang memperoleh pembelajaran ekspositori.

Berdasarkan hasil penelitian ini direkomendasikan bahwa model pembelajaran SSCS dapat digunakan sebagai alternatif untuk mengembangkankan kemampuan berpikir kreatif matematis. Selain itu, direkomendasikan pula bahwa pengembangan kemampuan berpikir kreatif matematis siswa perlu dilakukan secara simultan.

\section{DAFTAR RUJUKAN}

Depdiknas. (2006). Kurikulum Satuan Tingkat Pendidikan. Jakarta: Departemen Pendidikan Nasional.

Guilford, J. P. (1973). Characteristics of Creativity. Illinois State Office of the Superintendent of Public Instruction, Springfield. Gifted Children Section. (Online), ( http://files.eric.ed.gov/fulltext/ED080171.pdf)

Indrawan, R., \& Yaniawati, R.P. (2014). Metodologi Penelitian (Kuantitatif, Kualitatif, dan Campuran untuk Manajemen, Pembangunan, dan Pendidikan). Bandung: Reflika Aditama

Lartson, C.A. (2013). Effects of Design-Based Science Instruction on Science Problem-Solving Competency among Different Groups of High-School Traditional Chemistry Students. A thesis submitted to the Faculty of the Graduate School of the University of Colorado in partial fulfillment of the requirements for the degree of Doctor of Philosophy Educational Leadership \& Innovation.

McGregor, D. (2007). Developing Thinking Developing Learning. Poland: Open University

Press.

(Online),

http://vct.qums.ac.ir/Portal/file/\%3F180494/Developing\%2520thinking_\%2 520developing\%2520learning.pdf)

Munandar, U. (1999). Pengembangan Kreativitas Anak Berbakat. Jakarta: Reneka Cipta.

Park, H. (2004). The Effects of Divergent Production Activities With Math Inquiry 
and Think Aloud of Students With Math Difficulty. Disertasi. (Online), (http://repository.tamu.edu/bitstream/handle/1969.1/2228/etd-tamu-2004AEPSY-Park-1.pdf)

Pehnoken, E. (1997). The State-of-Art in Mathematical Creativity. Zentralblatt für Didaktik der Mathematik (ZDM) - International Reviews on Mathematical Education. Volume 29 (Juni 1997) Nomor 3. ISSN 1615-679X. (Online), (http://www.emis.de/journals/ZDM/zdm973a1.pdf)

Pizzini, E.L., Abel, S.K, \& Shepardson, D.P. (1988). Rethinking Thingking in the Science Classroom. The Science Teacher, December 1988, (Online), (http://plato.acadiau.ca/COURSES/Educ/GMacKinnon/EDUC4143/graphics /Rethinking\%2520thinking.pdf)

Ruseffendi, E. T. (2006). Pengantar Kepada Membantu Guru Mengembangkan Kompetensinya dalam Pengajaran Matematika untuk Meningkatkan CBSA. Bandung: Tarsito

Sabandar, J. (2008). “Thinking Classroom” dalam Pembelajaran Matematika di Sekolah.

(Online), (http://file.upi.edu/Direktori/FPMIPA/JUR._PEND._MATEMATIKA/1947 05241981031-

JOZUA_SABANDAR/KUMPULAN_MAKALAH_DAN_JURNAL/Thinki ng-Classroom-dalam-Pembelajaran-Matematika-di-Sekolah.pdf) 